\title{
Giant Cumulated Condyloma (Tumor of Buschke Lõwenstein). Presentation of a Case
}

\author{
Dr. Juan Francisco Rodríguez Reyes ${ }^{1}$, Dr. Jorge Agustin Satorre Rocha ${ }^{1}$, Dr. Pedro Rolando \\ López Rodríguez ${ }^{3}$, Dr. José Antonio Hernández Varea² ${ }^{2}$ Dr. Olga Caridad Leòn Gonzalez ${ }^{1}$ \\ ${ }^{1} 1$ st grade and Assistant Professor of General Surgery, Clinic "Cira Garcia”, Havana, Cuba. \\ ${ }^{2} 1$ st and 2nd grade and Assistant Professor of Surgery, Clinic "Cira Garcia", Havana, Cuba. \\ ${ }^{3} 1$ st and 2nd grade and Consultant Professor in Surgery, Clinic "Cira Garcia”, Havana, Cuba. \\ lopezp@infomed.infomed.sld.cu
}

*Corresponding Author: Dr. Pedro Rolando Lòpez Rodrìguez, 1st and 2nd grade and Consultant Professor in Surgery, Clinic “Cira Garcia”, Havana, Cuba.

\section{Abstract}

The condylomataacuminataor genital warts are produced by the human papiloma virus. Infection typically occurs when host basal cells are exposed to viral infection through a damaged epitelial barrier, such as during sexual inter course or as a product of other minor skin abrasions. In few occasions they can evolve with a marked growth and cause the well-known Buschke-Löwenste in sindrome or Giant Condiloma Acuminado. We present a patient with Giant Condyloma Accumulated in the inguinal and anal regions that was surgically treated with exeresis of the inguinal lesions and electro fulguration of the annals with satisfactory evolution, without tumor recurrence at three months.

Keywords: Giant Condiloma Accuminado. Warty carcinoma.

\section{INTRODUCTION}

Condylomataacuminata or genital warts are one of the most common sexually transmitted diseases. They are produced by the human papillomavirus. Infection typically occurs when host basal cells are exposed to viral infection through a damaged epithelial barrier, such as during sexual intercourse or as a product of other minor skin abrasions $(1,2)$.

The presence of other associated factors is necessary to produce the disease such as: sexual promiscuity, poor nutrition, smoking, depression of the immune system and prolonged use of oral contraceptives. (1, 2, 3)

On rare occasions they can evolve as an invasive tumor with local malignancy, although without metastasis, equivalent to a verrucous carcinoma and it is when they are diagnosed as Buschke-Löwenstein syndrome or tumor.

\section{Presentation of the Case}

Male patient I.K.M. 47 years old, Bahamés, who attended the surgery clinic of the Central Clinic "Cira García" for presenting skin lesions in the inguinal and anal region of 5 years of evolution that have been growing progressively. It started as a "little ball" until it reached the size of a tumor lesion approximately $20 \mathrm{cms}$. high, of semi-hard consistency. Therefore, their admission is decided for study and surgical treatment.

Upon entry. Physical examination: verrucous lesion of exophytic growth located in the scrotum and perineum of $10 \mathrm{~cm}$ in diameter, without presence of suppuration or signs of ulceration (fig.1) and another verrucous lesion in right inguinal region, pedunculated approximately $20 \times 15 \mathrm{~cm}$ in diameter. 5 years of evolution. 
Giant Cumulated Condyloma (Tumor of Buschke Lõwenstein). Presentation of a Case
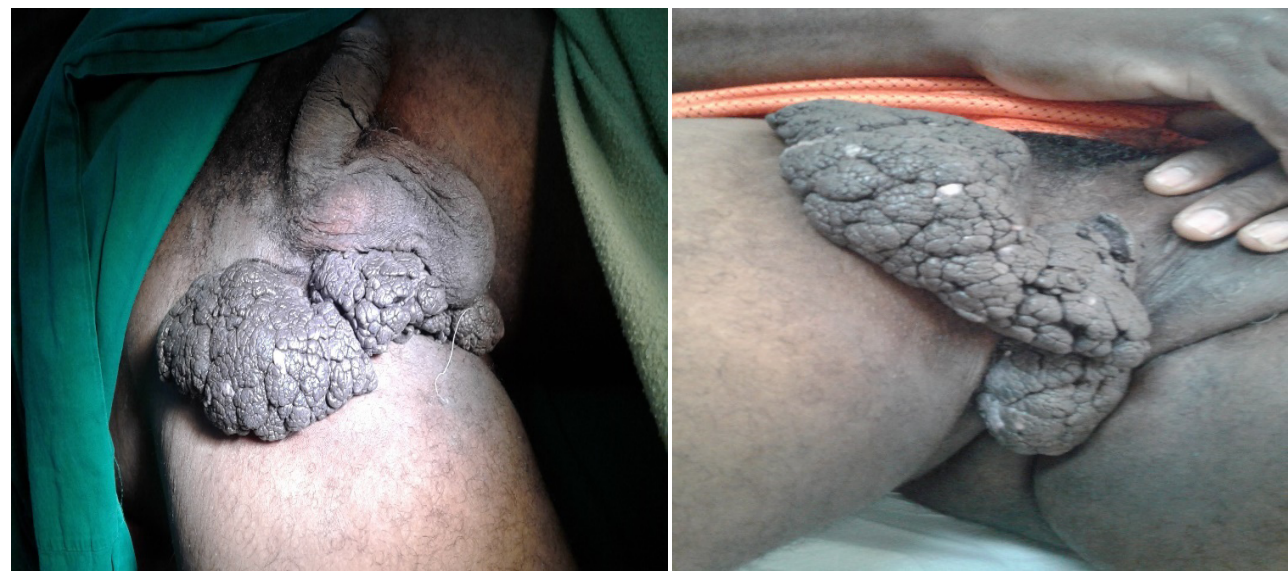

Fig. 1 \& 2. Condylomatous tumor lesion in the right inguinal region.
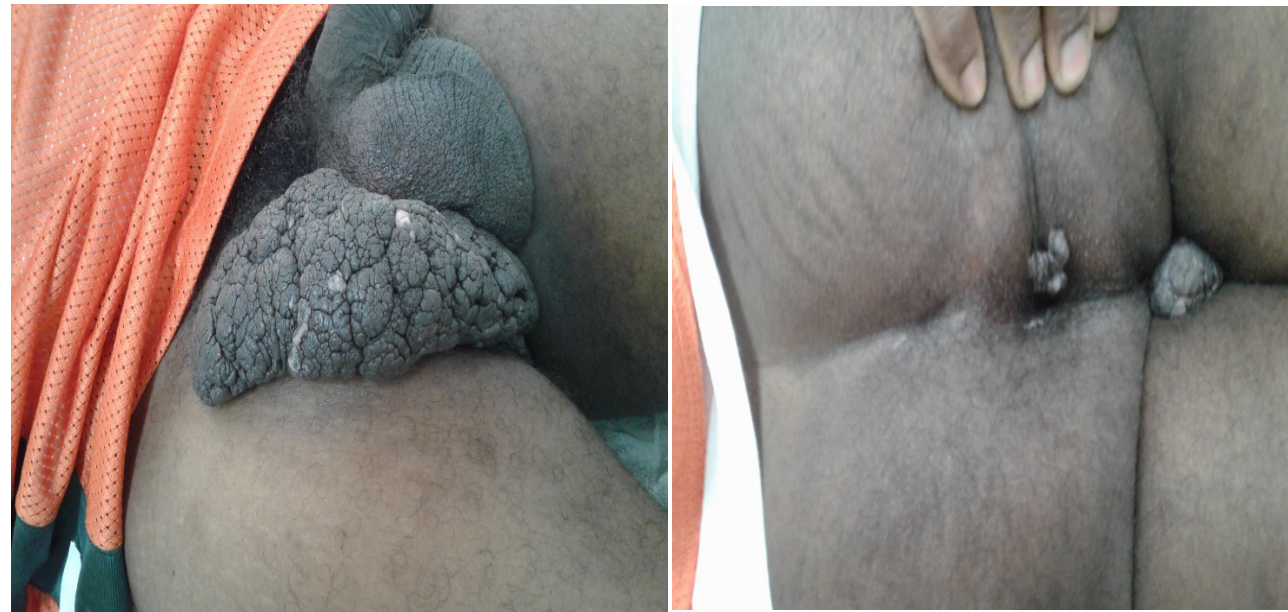

Fig. 3 \& 4. Condylomatous tumor lesion in the right inguinal region and anal region where the large semi-hard verrucous consistency is observed
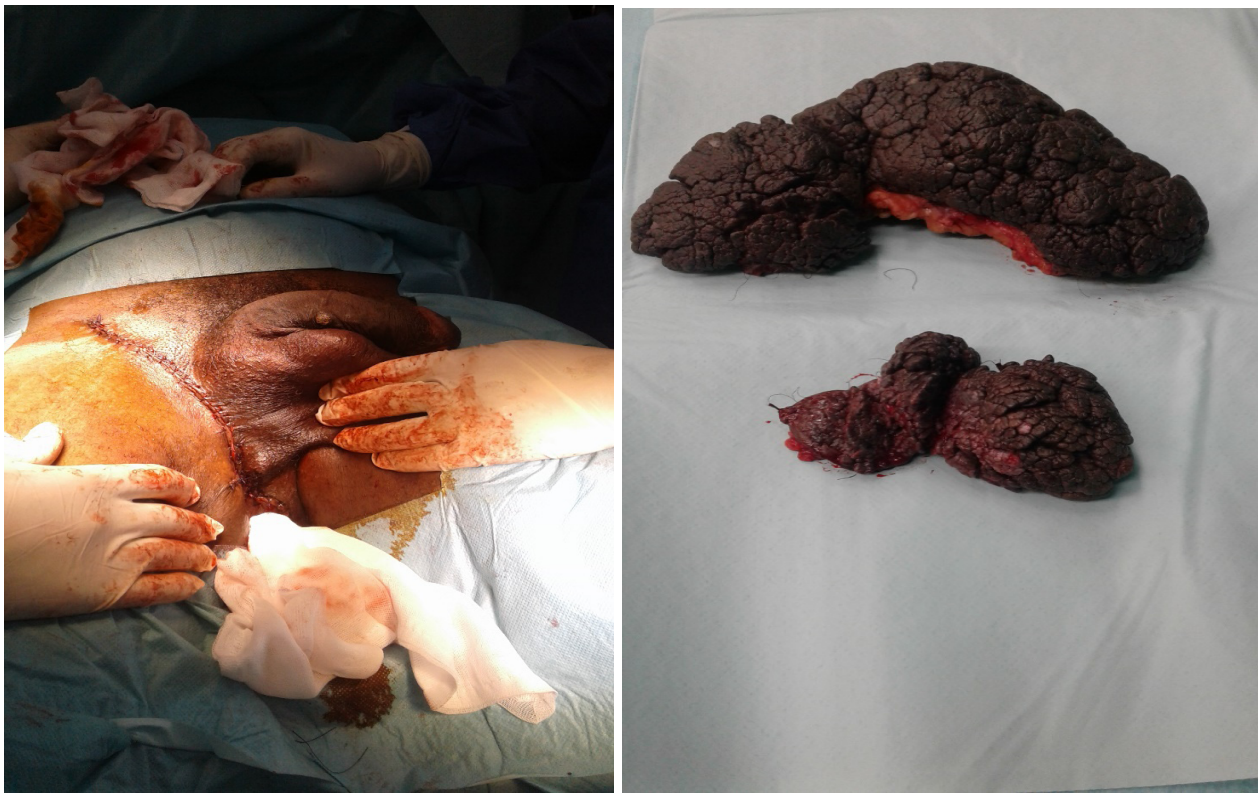

Fig. 5 \& 6. Closure of the inguinal area and surgical piece sent to the Department of Pathology. 
Hematological and serological check was carried out: involvement was observed.

Hemoglobin 13.5 g / l, Hto. 0.45 leukogram 7.5 x 10 / 1

Erythro 18, blood glucose $5.54 \mathrm{mml}$, Cituria Negative,

HIV negative, Serology, non-reactive, platelet count

321 x $10 \mathrm{~g} / \mathrm{l}$. Thorax Rx Normal. Normal nasal and pharyngeal exudate.

Rectosigmoidoscopy: No internal injury, no anal canal

He underwent a complete excision of the lesion of the inguinal region and electro-fulguration of the perianal lesion. It was not necessary to perform the plastic reconstruction given the pedunculated characteristic of the inguinal lesion that was completely resected.

\section{Histological Study}
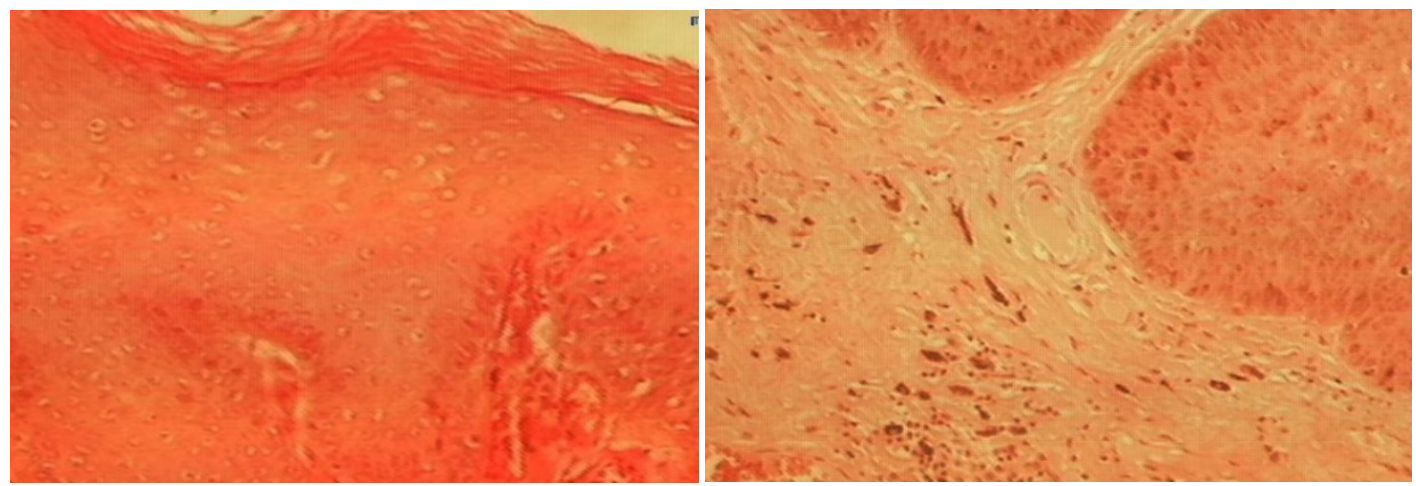

Fig. 7 \& 8. Hyperkeratosis with severe acanthosis with basal hyperplasia and increased melanin pigment at that level.
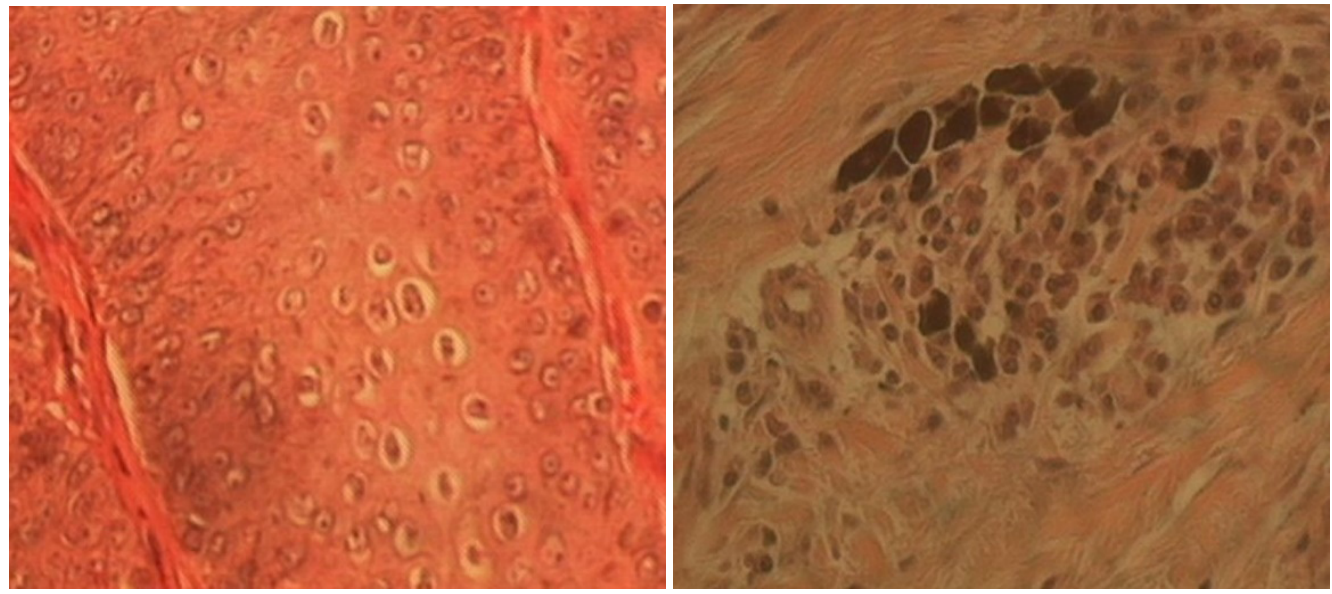

Fig. 9 \& 10. Presence of coilocytes in the epidermis and melanophores in the superficial dermis.

Histologically (Fig. 7, 8, 9 \& 10) there was marked hyperkeratosis and acanthosis and areas of parakeratosis with moderate spongiosis and areas of basal hyperplasia with increased melanin pigment in the basal cells with malignant cells and nucleoli prominent rosés with inclusion bodies in the epidermis. Severe papillomatosis with increased vascularization and the presence of giant cells of the foreign body type with the presence of melanoforos and chronic inflammatory infiltrate in the superficial and middle dermis.

The diagnosis was concluded as a giant Condilomatosis or Buschke-Lowenstein tumor.
The patient progressed satisfactorily and remains in follow-up bySurgery. There have been no recurrences after three months of surgery.

\section{Discussion}

The Buschke-Lowenstein tumor is a rare variant genital condyloma associated with infection by HPV strains 6 and 11. The average age of presentation is under 50 years, with a predominance of men in a 3 : 1 ratio. It is a pre-malignant lesion, considered an atomopathologically between condyloma acuminatum and perianal squamous cell carcinoma, which explains its high morbidity and mortality. It is characteristically 
Giant Cumulated Condyloma (Tumor of Buschke Lõwenstein). Presentation of a Case

bulky (more than $10 \mathrm{~cm}$ in diameter) and slowgrowing and exophytic with a tendency to invade and destroy the tissues on which it sits. $(5,6$, $)$

Among the risk factors that predispose to suffer from this pathology we can find: immuno suppression (mostly with HIV positive), homosexuality, promiscuity, poor genital hygiene, chronic genital infections, malnutrition and alcoholism. Freed to its free evolution, this tumor can spread intraanally, fistulize, become infected, recur once it is operated (66\%) or undergo malignant transformation (56\%). (7. 8)

The Buschke-Lowenstein tumor does not present cellular atypia, it is a benign tumor, but in $30 \%$ of cases it can be malignant; nevertheless, due to the great power it has of recurrence, it is considered by some authors as a malignant tumor. $(9,10$.)

The differential diagnosis of Buschke-Lowenstein tumor will be made with other pathologies of genital location among them: Bowen's disease in its condylomatous form, pseudo-epitheliomatous balanitis caused by fungi, spinocellular epitheliomas, warty carcinomas, syphilis, lymphogranulomatosis venereum (Nicolás disease) Favre). The difference of the giant acuminate condyloma is that it is more proliferating and penetrates deeper tissues than squamous cell tumors, respects the basement membrane and does not metastasize. Of the rest of the pathologies raised is discarded by serology and other complementary. $(8,11,12)$.

Regarding treatment, the most appropriate option is the radical surgical excision of the lesions and their anatomopathological study. Some cases may even require abdomino-perineal amputation. Other treatments that have been used in some cases are chemo and radiotherapy, as well as topical treatments although the available bibliographic evidence is not conclusive regarding the systematic use of them, tending in general terms to be ineffective. (12, $13,14)$.

\section{ConCLUSiONS}

Definitive diagnosis: Tumor of Buschke Lõwensteinor Condiloma Accuminado Gigante

Surgical treatment: excision of inguinal lesions and electro fulguration of anal lesions.
Evolution: Satisfactory. Therehave been norecurrences in the assessment performed at 3 months.

\section{REFERENCES}

[1] Gearhart PA, Randall TC, Buckley RM. Human papillomavirus [En línea]. 2006. [citado: enero 11 de 2007]. Disponible en: http://www.emedicine. com/med/topic1037.htm

[2] Quyen D. Chu,Michael P. Vezeridis,N. Peter Libbey,Harold J. Wanebo. "Giant Condyloma Acuminatum (Buschke-Lowenstein Tumor) ofthe Anorectal and Perianal Regions. Analysisof 42 Cases". Dis Colon Rectum, Vol. 37, No. 9, September 1994.

[3] Sukru Tas, Muhammet Kasim Arik, Faruk Ozkul, Oztekin Cikman, and Yilmaz Akgun”Perianal Giant Condyloma Acuminatum-BuschkeLowenstein-Tumor: A Case Report". Hindawi Publishing Corporation. Case Reports in Surgery. Volume 2012, Article ID 507374.

[4] W.GardnerRhea, Jr., Brian M. Bourgeois, Daniel R. Sewell. “Condyloma Acuminata: A Fatal Dysease?. The American Surgeon, Volume 64, November 2017.

[5] Ruiz de la Hermosa A., Hurtado Caballero E., Zorrilla Ortúzar J.,Del Valle Hernández E., Muñoz Jimenez F. "Caso clínico: Tumor de Buschke-Lowenstein asociado a condilomatosis nasofaríngea". Editorial Elsevier México. Revista de Gastroenterología de México 2011; 76(3):275278.

[6] Alexander Kreuter, Ulrike Wieland. "Giant Condyloma Acuminatum of Buschke and Löwenstein. Case Report". The New England Journal of Medicine, Volume 365; 17. October 27, 2011.

[7] Rodríguez González D, Pérez Piñero J, Sarduy Nápoles M. Infección por el virus del papiloma humano en mujeres de edad mediana y factores asociados. Rev Cuba Obstet. Ginecol. junio de 2014;40(2):218-32.

[8] Vega-Malagón, Genaro, et al. Infección por el virus del papiloma humano, biología molecular. EuropeanScienticJournal, 2017; vol. 10, no 18. http://www.eujournal.org/index. php/esj/ article/view/3604 
Giant Cumulated Condyloma (Tumor of Buschke Lõwenstein). Presentation of a Case

[9] Pennacchiotti G, Sáez R, Martínez MJ, Cárcamo M, Montes R. Prevalencia del virus papiloma humano en pacientes con diagnóstico de carcinoma escamoso de la cavidad oral. RevChil Cir. abril de 2016;68(2):137-42.

[10] Fernández, Isai Arturo Medina, etal.Conocimiento del virus del papiloma humano y su vacuna por parte de mujeres de una zona rural de Querétaro, México. Revista Enfermería Costa Rica. 2017; no 32, p. 2. 75CIMEL 2017, Volumen 22, Número 1

[11] García, Lia Barrios, et al. Factores de riesgo presentes en pacientes con lesiones intraepiteliales escamosas del cérvix en la Clínica Maternidad Rafael Calvo en la ciudad de Cartagena (Colombia): estudio descriptivo. Archivos de Medicina (Manizales). 2016;16(1):109-117.
[12] Morales L Liliana A., Rincón R Diego F., Rincón Orozco Bladimiro. Avances en el desarrollo de nuevas vacunas profilácticas y terapéuticas contra el Virus del Papiloma Humano. Rev. Univ. Ind. Santander. Salud [Internet]. 2016 Sep [cited 2017 Jan 10] ; 48( 3 ): 385-391.

[13] Pinto Bustamante Boris Julian. La vacuna contra el Virus del Papiloma Humano: estado de la cuestión, principio de proporcionalidad y consentimiento informado. Acta bioeth. 2016 Nov.; 22( 2 ): 251-261.

[14] González Martínez G, Núñez Troconis J. Tratamiento de las verrugas genitales: una actualización. Rev. Chil. Obstet. Ginecol. 2015; 80(1):76-83.

Citation: Dr. Juan Francisco Rodríguez Reyes, Dr. Jorge Agustin Satorre Rocha, Dr. Pedro Rolando López Rodríguez, et al. Giant Cumulated Condyloma (Tumor of Buschke Lõwenstein). Presentation of a Case. Open Access Journal of Internal Medicine. 2019; 2(2): 10-14.

Copyright: (c) 2019 Dr. Juan Francisco Rodríguez Reyes, Dr. Jorge Agustin Satorre Rocha, Dr. Pedro Rolando López Rodríguez, et al. This is an open access article distributed under the Creative Commons Attribution License, which permits unrestricted use, distribution, and reproduction in any medium, provided the original work is properly cited. 